\title{
Job Sheet Learning Media on Briquette Production from Coffee Grounds and Soybean Peel with Various Compositions and Particle Sizes for Vocational High School Students
}

\author{
Asep Bayu Dani Nandiyanto*, Sarah Istiqomah Widiaputri, Shinta Maharani, Risti Ragadhita \\ Universitas Pendidikan Indonesia, Jl. Dr. Setiabudi No. 229 Bandung, Indonesia \\ nandiyanto@upi.edu,sarah@upi.edu,shinta.maharani@upi.edu,ristiragadhita@student.upi.edu
}

\begin{abstract}
The purpose of this study was to determine the learning outcomes of Vocational High School students about biobriquette using learning media in the form of instructional video and job sheet through experimental demonstration. The study was conducted through the pretest, theoretical explanation of briquettes using video learning, the first posttest, the presentation of material using job sheet media, and the second posttest. Briquettes production was done through drying, carbonizing, grinding carbon using a sawmill, sieving, molding, and drying. In the briquettes production, we varied the composition ratios between coffee grounds and soybean peel (i.e. 50:50; 60:40; 70:30; 80:20; and 90:10) and particle sizes (i.e. 1000, 600, and $250 \mu \mathrm{m}$ ), which were mixed with tapioca flour as the binder. Physical characteristics of briquettes were analyzed through some analyses. Based on the physical characteristic results of briquettes, briquettes at ratio $(60: 40)$ with a particle size of $250 \mu \mathrm{m}$ have good Compressed Density (CD), Burning Rate (BR), and Specific Fuel Consumption (SFC) characteristics. Based on the evaluation of the pretest and posttest results, the learning media improved students' knowledge and understanding of biobriquette. This study brings new information about the need for biobriquette learning media with experimental methods to improve vocational students' comprehension.
\end{abstract}

Keywords: Biobriquettes, Coffee Grounds, Job Sheet, Learning media, Soybean Peel, Vocational

\section{Corresponding Author}

*Universitas Pendidikan Indonesia, Jl. Dr. Setiabudi

No. 229 Bandung, Indonesia

*nandiyanto@upi.edu

\section{Introduction}

Vocational high school (VHS) is an educational institution with a variety of expertise programs that aim to prepare students to work in certain fields (Maknun, Barliana, and Cahyani, 2019). In the Expertise Program of Agricultural Product Processing Agribusiness, students are prepared to become skilled workers in the agroindustry and be able to become entrepreneurs in the field of Agricultural Product Processing Technology (Handayani, Ali, Wahyudin, and Mukhidin, 2020). In the learning process at VHS, students learning activities in the classroom are also equipped with various practical activities of processing agricultural produce into processed goods that are ready to be sold to consumers (Rahman, 2020; Safitri, Handayani, and Mujdalipah, 2018). Products that are processed from agricultural products produce waste, usually in the form of peel, pulp, and seeds (Pandey and Dwivedi, 2020; Agustono, Lamid, Ma'ruf, and Purnama, 2017).

One of the efforts in handling agricultural waste is through processing the waste into a source of biomass energy, for example, being used for the production of biobriquettes. Biobriquettes are briquettes made from biological materials or biomass. Biobriquettes have the advantages of relatively high-heat flame, more economical, chemical-free, and smokeless (Tippayawong, Santiteerakul, Ramingwong, and Tippayawong 2020; Brunerová, Roubík, Brožek, Herák, Šleger, and Mazancová, 2017). Agricultural waste that has the potential to be processed into a source of biomass energy with abundant availability is coffee grounds and soybean peel. Coffee grounds briquettes produce a calorific value of $5600 \mathrm{cal} / \mathrm{g}$ (Anam, 2019). Soybean peel briquettes produce a calorific value of $5569.97 \mathrm{cal} / \mathrm{g}$ (Fauzie, 2019). Based on the calorific value produced by coffee grounds and soybean peel, both of them have the potential to be used as raw materials in briquettes production.

The utilization of coffee grounds and soybean peel in biobriquette production is needed to improve vocational students' understanding regarding the use of agricultural waste and alternative energy sources. Students' 
understanding is improved through the implementation of practicum which is supported by job sheets as a learning media. Job sheets are practical teaching materials developed to facilitate students and teachers in carrying out practicum (Widyastuti and Utami, 2018). Job sheets are used by students as a guide during practicum to assist students in completing work according to instructions, thus, reduce product failure rate (Alhusaeri, Asmilah, and Al-Rizky, 2020).

At this time there are many studies on job sheets for vocational students. Wahyuraidha (2020) explained the making of job sheets in the refresher product processing practicum increases students' creativity. Hendarmin (2019) explained the achievement of coffee production competencies by students after using SKKNI-based job sheet obtained very good results. Maharani (2018) stated that the use of job sheets to support the achievement of students' cognitive and psychomotor abilities obtained very good optimum scores. However, research on briquette production job sheets to be used by vocational students during practicum has not been developed much. Therefore, the material about briquettes is important to vocational students, especially in the Agricultural Product Processing Agribusiness Expertise Program due to its relation to the handling and processing of agricultural waste.

Thus, research on job sheet learning media that supports the understanding of vocational high school students about briquettes production based on coffee grounds and soybean peel is needed. This study aims to determine the differences in the learning outcomes of VHS students about briquette production with variations in the composition and particle size of coffee grounds and soybean peel using video learning media and a job sheet. The research method used was an experimental demonstration. The experimental demonstration was carried out by presenting new knowledge to vocational high school students to improve students' understanding.

\section{Method}

\subsection{Briquette Production}

The materials used in briquettes production are coffee grounds, soybean peel, tapioca flour, and water. The coffee grounds used are a mixture of Arabica coffee and Robusta coffee that was obtained from coffee shops in Bandung. Soybean peel got from the by-product of pastry processing in Cianjur Regency. The apparatuses used are a scale, baking sheet, oven, thermometer, saw-mill, Tyler sieve, briquette molds, beaker, furnace, and a lighter.

Briquette production was conducted by drying the coffee grounds and soybean peel in the oven (at $85^{\circ} \mathrm{C}$; for $4-7 \mathrm{~h}$ ) and carbonizing (at $200^{\circ} \mathrm{C}$; for $1-2 \mathrm{~h}$ ). The biomass carbon from the carbonization process was then milled using a sawmill and sieved using a Tyler sieve to obtain variations in the size of the biobriquette particles of 1000, 600, and $250 \mu \mathrm{m}$. After that, the biomass carbon was weighed according to the ratio of coffee grounds to soybean peel (i.e. 50:50; 60:40; $70: 30 ; 80: 20 ; 90: 10)$, and added tapioca flour as a binder
$(30 \% \mathrm{w} / \mathrm{w})$. The mixture of ingredients was added to boiling water while stirred until smooth and molded using a cylindrical mold (diameter $=3.5 \mathrm{~cm}$, height $=1 \mathrm{~cm}$ ) with a pressure of $14.75 \mathrm{~N} / \mathrm{m}^{2}$. The briquettes that have been molded were dried in the oven (at $135^{\circ} \mathrm{C}$; for $2-3 \mathrm{~h}$ ). Dried briquettes were weighed periodically until briquettes achieve a constant weight. Figure 1 shows the flow chart of the briquette-production process.

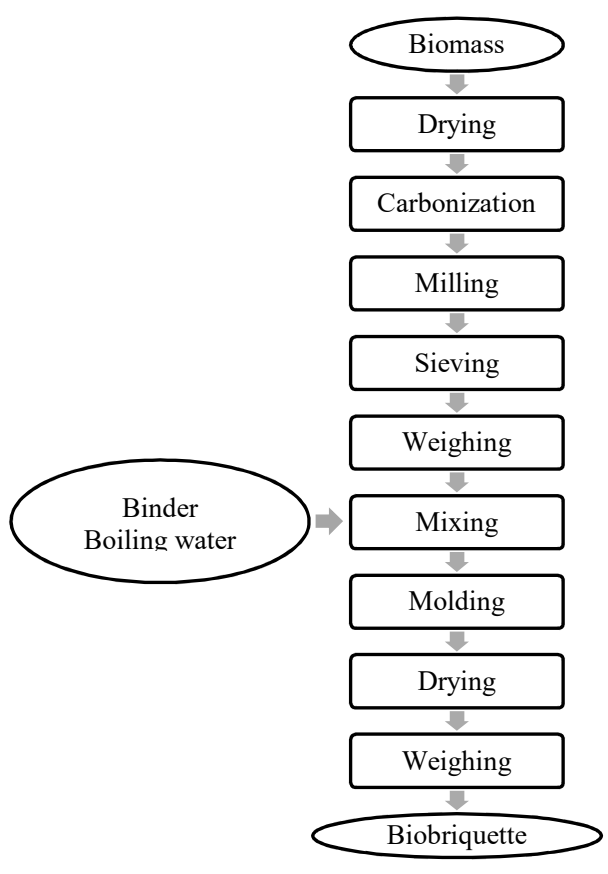

Fig. 1 Flow Chart of Briquette Production

The physical characteristics analysis of the briquettes was carried out through the Compressed Density (CD) test to determine the density of the briquettes after being removed from the mold, Relaxed Density (RD) to determine the density of briquettes after drying, Relaxation Ratio (RR) to determine the ratio of the $\mathrm{CD}$ and $\mathrm{RD}$ values, Percentage of Moisture Content (PMC) to determine the percentage of briquette moisture content, Percentage of Durability Index (PDI) to determine the resistance of briquettes to crack during storage, Percentage of Water Resistance Index (PWRI) to determine the percentage of water content absorbed by the briquette (at $27^{\circ} \mathrm{C}$; for $30 \mathrm{~s}$ ), Burning Rate (BR) to determine the average mass of briquettes that have burned out, and Specific Fuel Consumption (SFC) to determine the ratio of the mass of briquettes burned to the amount of water boiled.

\subsection{Research Subject}

The subjects in this study were 17 students of eleventh grade from vocational high school studying Agribusiness Expertise Program in Agricultural Product Processing in Kota Jakarta Selatan, Indonesia.

\subsection{Student Learning Process}

The study was conducted in five stages of the learning process with an evaluation of the results at each stage. First, 
students completed the pre-test to find out their understanding before learning about briquettes. Students watched the learning video to understand the theory, process production, and testing the briquettes. After that, students completed the first posttest to analyze students understanding after learning. Students were asked to read job sheets to understand the theory, production process, and testing of briquettes on laboratory-scaled practicum. Then, students completed the second posttest to determine the increase in student understanding after reading the job sheet.

\subsection{Preparation of Job Sheet}

The preparation of the job sheet was done by determining the appropriate subjects, analyzing the basic competencies to be achieved, determining the time to complete the practicum, specifying the tools and materials needed, and compiling brief information descriptions, work steps, and reports that must be done.

\subsection{Job Sheet Learning Evaluation}

Learning evaluation using a job sheet was carried out to determine the level of students' ability to understand new knowledge. Job sheet evaluation was done by completing pretest and posttest questions. The scores that have been obtained from the pretest and posttest processed by comparing the students' achievement in answering the questions correctly on the pretest and posttest. The pretest and posttest questions carried out by students are:

1. Biobriquettes are briquettes made from biological materials or biomass.

2. Biobriquettes are briquettes that can be used repeatedly after a flame as fuel.

3. The principle of compaction in the briquetteproduction process is to change the energy density to increase the density and reduce the water content of biomass.

4. Carbon material for briquettes is obtained from the carbonization process of agro-industrial waste. Then, briquettes are made by mixing carbonized raw materials with adhesive materials. Carbonization is the process of converting organic material into charcoal.

5. Carbon material for briquettes is obtained from the carbonization process of agro-industrial waste. Then, briquettes are made by mixing carbonized raw materials with adhesive materials. Good briquettes are briquettes that have a high carbon content.

6. Carbon material for briquettes is obtained from the carbonization process of agro-industrial waste. Then, briquettes are made by mixing carbonized raw materials with adhesive materials (binder). The purpose of adding adhesive to the briquettes is to attract water and form a solid texture by binding the raw material components.

7. Carbon material for briquettes is obtained from the carbonization process of agro-industrial waste. Then, briquettes are made by mixing carbonized raw materials with adhesive materials (binder). The greater the amount of adhesive, the higher the water content and ash content and increase the calorific value of the briquettes.

8. Carbon material for briquettes is obtained from the carbonization process of agro-industrial waste. Then, briquettes are made by mixing carbonized raw materials with adhesive materials (binder). Once formed, the briquettes are dried. The water content in the briquettes is calculated by comparing the mass of water contained in the briquettes with the mass of the briquettes after drying.

9. Carbon material for briquettes is obtained from the carbonization process of agro-industrial waste. Then, briquettes are made by mixing carbonized raw materials with adhesive materials (binder). High water content in briquettes can reduce the calorific value of briquettes.

10. Carbon material for briquettes is obtained from the carbonization process of agro-industrial waste. Then, briquettes are made by mixing carbonized raw materials with adhesive materials (binder). The size of the carbon particles can affect the quality of the briquettes.

11. Carbon material for briquettes is obtained from the carbonization process of agro-industrial waste. Then, briquettes are made by mixing carbonized raw materials with adhesive materials (binder). The quality of briquettes is influenced by the amount, type and size of raw materials that have been carbonized.

12. Carbon material for briquettes is obtained from the carbonization process of agro-industrial waste. Then, briquettes are made by mixing carbonized raw materials with adhesive materials (binder). The larger the size of the carbonized raw materials, the lower the thermal efficiency and calorific value per volume of the briquettes.

13. Carbon material for briquettes is obtained from the carbonization process of agro-industrial waste. Then, briquettes are made by mixing carbonized raw materials with adhesive materials (binder). The density of briquettes is influenced by the molding pressure, the amount of adhesive, and the type and size of the raw material being carbonized.

14. Carbon material for briquettes is obtained from the carbonization process of agro-industrial waste. Then, briquettes are made by mixing carbonized raw materials with adhesive materials (binder). The smaller the size of the carbonized raw material, the higher the density of the briquettes so that the briquettes are stronger (not brittle).

15. One of the parameters in briquettes is the specific fuel consumption (SFC), where SFC is the amount of briquette used to produce energy. The higher the SFC, the better the quality of the briquettes (more economical). 


\section{Results and Discussion}

\subsection{Experimental Results}

\subsubsection{Compressed Density}

Figure 2 shows that the biobriquette with a composition of $60 \%$ of coffee grounds and $40 \%$ of soybean peel has the highest average $C D$ value at a particle size of $250 \mu \mathrm{m}$. A high $\mathrm{CD}$ value indicates a denser briquette. Biobriquette with a composition of $50 \%$ of coffee grounds and $50 \%$ of soybean peel at a particle size of $600 \mu \mathrm{m}$ has the lowest CD average value. Carbon particles measuring $250 \mu \mathrm{m}$ have smaller pores on the briquette so the briquettes are denser. This is in line with research conducted by Orisaleye, Jekayinfa, Adebayo, Ahmed, and Pecenka (2018) which states that the highest density of briquettes is obtained from using smaller particle sizes. In short, the compressed density is affected by the particle size (Priyant, Hantarum, and Sudarno, 2018). Overall, a decrease in the composition of coffee grounds and an increase in the composition of soybean peel decrease the compressed density as shown in Figure 2.

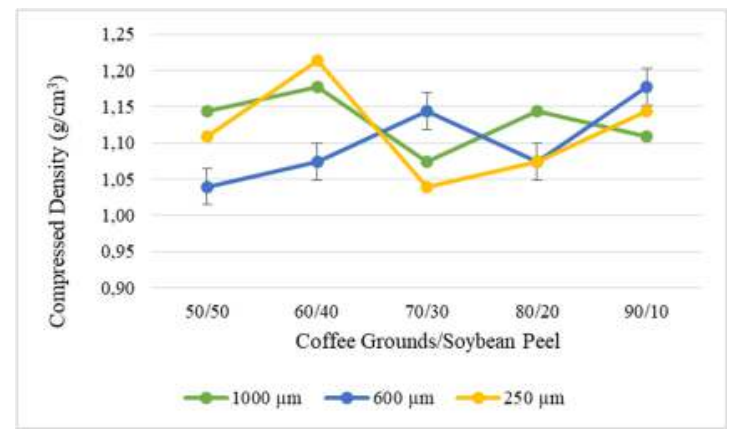

Fig. 2 Effect of Material Ratio and Particle Size on Briquette's Compressed Density

\subsubsection{Relaxed Density}

Figure 3 shows that the biobriquette with a composition of $70 \%$ of coffee grounds and $30 \%$ of soybean peel at a particle size of $600 \mu \mathrm{m}$ has the highest average RD value and the lowest average RD value at a particle size of $250 \mu \mathrm{m}$. This shows that the smaller the particle size, the higher the RD value. Higher density values indicate better-quality briquette because higher density briquettes are more carboncompact so the resulting calorific value is higher (Tumuluru and Fillerup, 2020; Orisaleye, Jekayinfa, Adebayo, Ahmed, and Pecenka 2018).

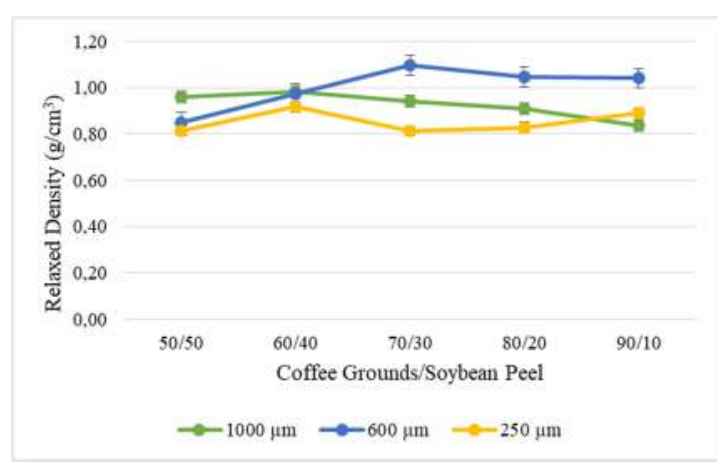

Fig. 3 Effect of Material Ratio and Particle Size on Briquette's Relaxed Density

\subsubsection{Relaxation Ratio}

Figure 4 shows that the biobriquette with a composition of $50 \%$ of coffee grounds and $50 \%$ of soybean peel has the highest average RR value at a particle size of $250 \mu \mathrm{m}$. Biobriquette with a composition of $80 \%$ of coffee grounds and $20 \%$ of soybean peel at a particle size of $600 \mu \mathrm{m}$ has the lowest average RR value. Briquettes of smaller particle size have a higher RR value because small particles rearrange bringing themselves closer together and reducing voids (Guo, Wang, Tabil, and Wang, 2016). High-density briquettes are caused by the stronger and denser bonds between the particles of the charcoal. The smaller particle size of charcoal can expand the bond area between the particles, thus increase the briquette density (Putri and Andasuryani, 2017).

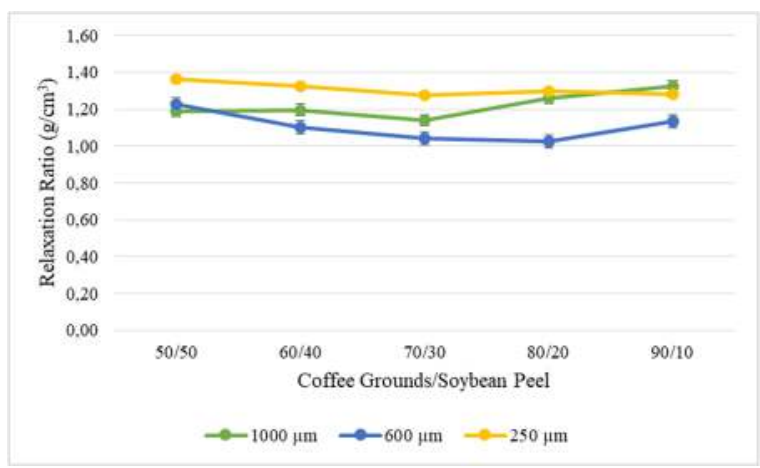

Fig. 4 Effect of Material Ratio and Particle Size on Briquette's Relaxation Ratio

\subsubsection{Percentage of Moisture Content}

Figure 5 explains that biobriquette with a composition of $50 \%$ of coffee grounds and $50 \%$ of soybean peel at a particle size of $250 \mu \mathrm{m}$ has the highest mean percentage of PMC and biobriquette with a composition of $80 \%$ of coffee grounds and $20 \%$ of soybean peel at a particle size of $600 \mu \mathrm{m}$ has the lowest average PMC value. The test results show that the particle size affects the moisture content of the briquettes (Purwanto, 2015). The lower the water content of the briquettes, the higher the heating value and combustion power. Briquettes with high moisture content are associated with difficulty to ignite and burn, and the increasing amount of smoke produced from burning (Siregar, 2020; Sunardi, Djuanda, and Mandra, 2019).

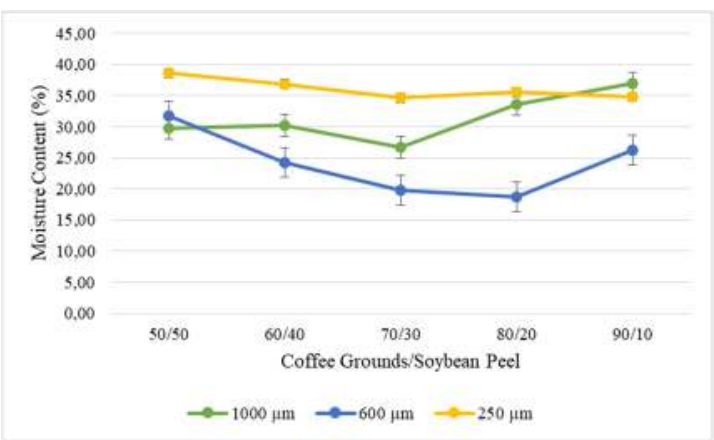

Fig. 5 Effect of Material Ratio and Particle Size on Briquette's PMC 


\subsubsection{Percentage of Durability Index}

Figure 6 explains that biobriquette with a composition of $60 \%$ of coffee grounds and $40 \%$ of soybean peel at a particle size of $1000 \mu \mathrm{m}$ has the highest average percentage of PDI and biobriquette with a composition of $70 \%$ of coffee grounds and $30 \%$ of soybean peel at a particle size of 600 $\mu \mathrm{m}$ has the lowest average PDI value. The results showed that the particle size affected the PDI value. Briquettes with a higher particle size of coffee grounds and soybean peel produce briquettes that are more resistant to impact. This is because the larger the particle size, the larger the briquette pores that are filled with material so the briquette is stronger (Lestari, Hasan, and Risna, 2017).

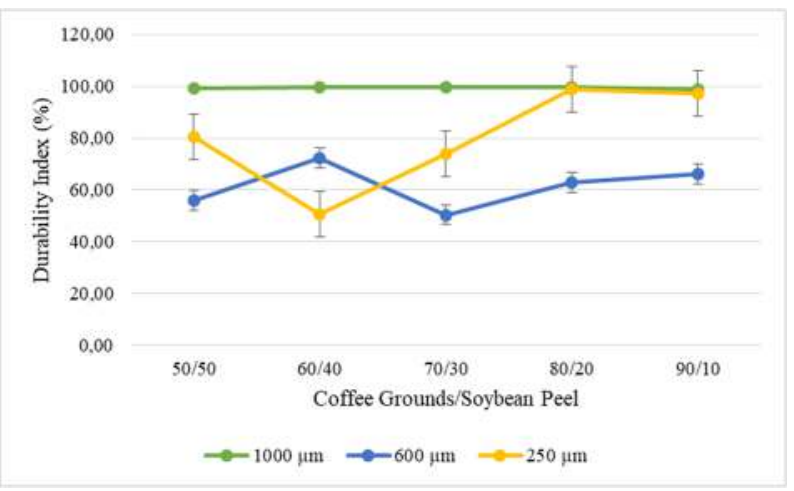

Fig. 6 Effect of Material Ratio and Particle Size on Briquette's PDI

\subsubsection{Percentage of Water Resistance Index}

Figure 7 displays the biobriquette with a composition of $80 \%$ of coffee grounds and $20 \%$ of soybean peel at a particle size of $1000 \mu \mathrm{m}$ has the highest average PWRI value and biobriquette with a composition of $50 \%$ of coffee grounds and $50 \%$ of soybean peel at a particle size of $600 \mu \mathrm{m}$ has the lowest PWRI mean value. The results show that the particle size affects the PWRI value. The smaller the particle size, the higher the PWRI value. This happens because the small particle size has a larger cavity, thus, water easily evaporates in the briquette drying process (Sunardi, Djuanda, and Mandra, 2019).

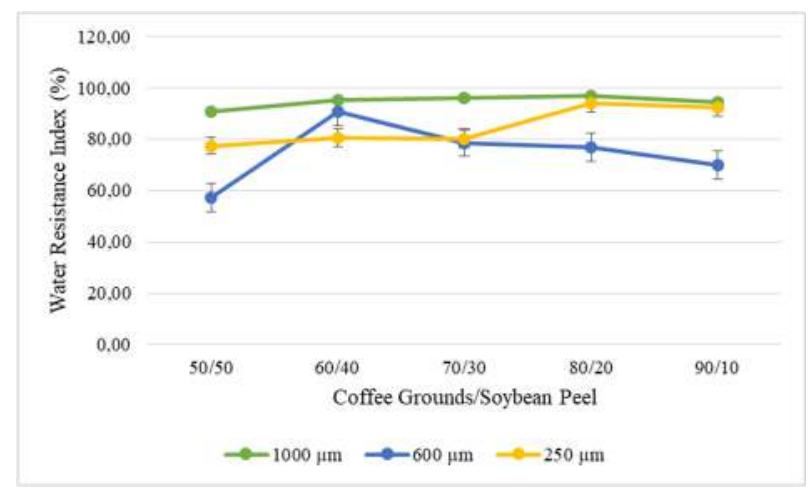

Fig. 7 Effect of Material Ratio and Particle Size on Briquette's PWRI

\subsubsection{Burning Rate}

Figure 8 shows that biobriquette with a composition of $60 \%$ of of coffee grounds and $40 \%$ of soybean peel at a particle size of $250 \mu \mathrm{m}$ has the highest average BR value and biobriquette with a composition of $50 \%$ of coffee grounds and $50 \%$ of soybean peel at a particle size of $1000 \mu \mathrm{m}$ has the lowest BR value. This is consistent with research by Pratama, Yudistira, Helwani, and Komalasari (2017) that the smaller the carbon particle size, the higher the bonded carbon therefore the heating value also be higher. The smaller the briquette particle size, the higher the burning rate of the briquette (burning rate). Briquettes with smaller particle sizes have lower porosity, thus increases the rate of heat transfer within biomass particles (Okot, Bilsborrow, and Phan, 2017).

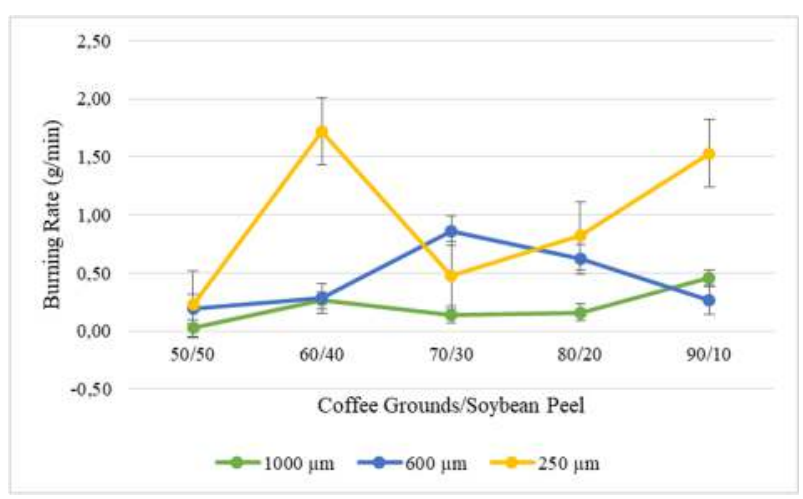

Fig. 8 Effect of Material Ratio and Particle Size on Briquette's Burning Rate

\subsubsection{Specific Fuel Consumption}

Figure 9 illustrates that the biobriquette with a composition of $50 \%$ of coffee grounds and $50 \%$ of soybean peel at a particle size of $1000 \mu \mathrm{m}$ has the lowest average SFC value. Biobriquette with a composition of $60 \%$ of coffee grounds and $40 \%$ of soybean peel at a particle size of 250 $\mu \mathrm{m}$ has the highest average SFC value. This is because coffee grounds have a higher calorific value than soybean peel, therefore, briquettes with a high percentage of coffee grounds have less fuel consumption. A low SFC value indicates less fuel consumption. The lower the SFC value indicates the better briquette quality (Nwabue Unah, and Itumoh, 2017).

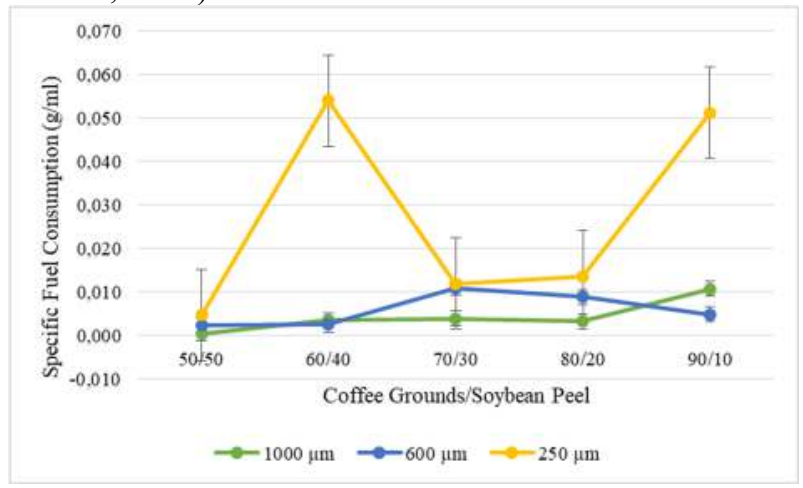

Fig. 9 Effect of Material Ratio and Particle Size on Briquette's SFC

\subsection{Students' Demographic Data}


Table 1 shows students' interest in general subjects taught in VHS. Students show different interests in each subject. Figure 10 shows the IQ score data obtained by students, students have a range of intelligence levels from 94 to 130 with variations in normal, superior, and very superior intelligence levels. The data obtained can be used to evaluate the best learning method according to students' interests and intelligence level (Nandiyanto Asyahidda, Danuwijaya, Abdullah, Amelia, Hudha, and Aziz, 2018).

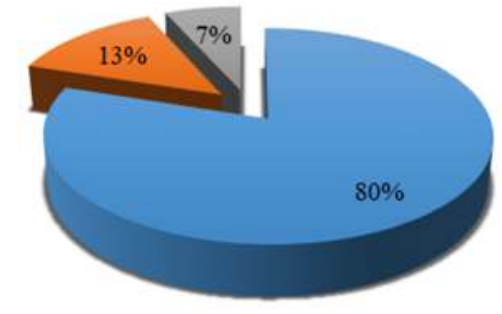

w Normal (80-119) $=$ Superior (120-129) $=$ Very Superior $(130-139)$ Fig. 10 Students' IQ Scores

Table 1. Student Average Score in Subjects

\begin{tabular}{|l|l|}
\hline \multicolumn{1}{|c|}{ Subject } & Score (\%) \\
\hline Mathematics & 79.84 \\
\hline Physics & 76.95 \\
\hline Chemistry & 75.58 \\
\hline Biology & 78.47 \\
\hline
\end{tabular}

\subsection{Learning Results}

Table 2 shows the acquisition score of the 15 items pretest and posttest by students. At the time before learning some students understood about briquettes and there were still students who did not understand about briquettes. This is due to the low level of students' knowledge about biobriquettes as an alternative fuel. The posttest is carried out after learning and providing the job sheet. The posttest results that have been analyzed show that students' understanding of briquettes increases after learning and giving job sheets.

Table 2. Score of Student Acquisition for Pretest and Posttest Questions

\begin{tabular}{|c|c|c|c|}
\hline \multirow{2}{*}{$\begin{array}{c}\text { Question } \\
\text { Number }\end{array}$} & \multirow{3}{|c|}{ Score (\%) } \\
\cline { 2 - 4 } & & \multicolumn{2}{|c|}{ Posttest } \\
\cline { 2 - 4 } & Pretest & $\begin{array}{c}\text { After } \\
\text { Video }\end{array}$ & $\begin{array}{c}\text { After } \\
\text { Job } \\
\text { Sheet }\end{array}$ \\
\hline 1 & 100.00 & 100.00 & 100.00 \\
\hline 2 & 52.90 & 52.90 & 58.80 \\
\hline 3 & 88.20 & 94.10 & 94.10 \\
\hline 4 & 88.20 & 94.10 & 88.20 \\
\hline 5 & 82.40 & 94.10 & 94.10 \\
\hline 6 & 82.40 & 94.10 & 82.40 \\
\hline 7 & 64.70 & 70.60 & 64.70 \\
\hline 8 & 88.20 & 82.40 & 88.20 \\
\hline 9 & 94.10 & 94.10 & 88.20 \\
\hline 10 & 82.40 & 88.20 & 94.10 \\
\hline 11 & 82.40 & 76.50 & 94.10 \\
\hline 12 & 47.10 & 17.60 & 41.20 \\
\hline 13 & 88.20 & 88.20 & 94.10 \\
\hline 14 & 76.50 & 82.40 & 58.80 \\
\hline
\end{tabular}

\begin{tabular}{|c|c|c|c|}
\hline \multirow{3}{*}{$\begin{array}{l}\text { Question } \\
\text { Number }\end{array}$} & \multicolumn{3}{|c|}{ Score (\%) } \\
\hline & \multirow[b]{2}{*}{ Pretest } & \multicolumn{2}{|c|}{ Posttest } \\
\hline & & $\begin{array}{l}\text { After } \\
\text { Video }\end{array}$ & $\begin{array}{c}\text { After } \\
\text { Job } \\
\text { Sheet }\end{array}$ \\
\hline 15 & 29.40 & 35.30 & 35.30 \\
\hline
\end{tabular}

Based on the learning results, Table 2 shows the increase and decrease in learning outcomes obtained by students. The results of the Paired t-Test in the first learning process using instructional videos show an insignificant effect $(\rho<0.05)$ on student learning outcomes with a value of $\rho=0.884$. The results of the Paired t-Test on the learning process using learning media in job sheets also show an insignificant effect $(\rho<0.05)$ on student learning outcomes with a value of $\rho=$ 0.793 . This is caused by the incomplete presentation of information on the learning media thus students do not understand the theory as a whole. In addition to the IQ score and the results of the acquisition of basic subject scores, the learning process that is insignificant to learning outcomes also be influenced by several factors, namely the learning environment, learning methods, and student learning motivation (Peterria and Suryani, 2016).

\section{Conclusion}

Based on the results of the physical characterization of briquettes, variations in the ratio of composition and the size of carbon particles of coffee grounds and soybean peel affect the quality of the biobriquette. Biobriquette based on coffee grounds and soybean peel at a carbon ratio (60:40) with a particle size of $250 \mu \mathrm{m}$ has the best quality with good CD, $\mathrm{BR}$, and SFC values for briquettes. Based on the evaluation of the results of the pretest and posttest, job sheets increase the knowledge and understanding of vocational students about briquettes. However, learning media in the form of videos and job sheets do not have a significant effect on learning outcomes. Job sheets for making biobriquettes based on coffee grounds and soybean peel can be used as a learning medium for students of the vocational school of Agribusiness Expertise for Agricultural Product Processing in increasing students' knowledge about efforts to use agricultural waste as a source of biomass in briquettes production.

\section{Acknowledgements}

We acknowledged Departemen Kimia and Program Studi Pendidikan Teknologi Agroindustri Universitas Pendidikan Indonesia for supporting this research. We acknowledged RISTEK BRIN for grant Penelitian Terapan Unggulan Perguruan Tinggi dan Bangdos Universitas Pendidikan Indonesia.

\section{References}

Agustono, B., Lamid, M., Ma'ruf, A., and Purnama, M. T. E. (2017). Identifikasi limbah pertanian dan perkebunan sebagai bahan pakan inkonvensional di Banyuwangi. Jurnal Medik Veteriner, 1(1), 12-22. 
Alhusaeri, M., Asmilah, W., and Al-Rizky, G. A. (2020). Pengembangan dan implementasi e-jobsheet teaching factory produksi roti berbasis SKKNI di SMK Negeri PP Cianjur. Undergraduate Thesis, Universitas Pendidikan Indonesia.

Anam, A. (2019). Pembriketan limbah padat kopi instan analisis persentase keberhasilan pencetakan. Jurnal Inovasi Ilmu Pengetahuan dan Teknologi, 1(1), 21-24.

Brunerová, A., Roubík, H., Brožek, M., Herák, D., Šleger, V., and Mazancová, J. (2017). Potential of tropical fruit waste biomass for production of bio-briquette fuel: Using Indonesia as an example. Energies, 10(12), 2119.

Fauzie, D. A. (2019). Pengaruh tekanan terhadap nilai kalor pada briket berbahan kulit kedelai. Undergraduate Thesis, Universitas Islam Indonesia.

Guo, L., Wang, D., Tabil, L. G., and Wang, G. (2016). Compression and relaxation properties of selected biomass for briquetting. Biosystems Engineering, 148, 101-110.

Handayani, M. N., Ali, M., Wahyudin, D., and Mukhidin, M. (2020). Green skills understanding of agricultural vocational school teachers around West Java Indonesia. Indonesian Journal of Science and Technology, 5(1), 21-30.

Hendarmin, N. P. (2019). Pengembangan jobsheet berbasis SKKNI untuk pencapaian kompetensi produksi kopi di SMK PPN Lembang. Undergraduate Thesis, Universitas Pendidikan Indonesia.

Lestari, L., Hasan, E. S., and Risna, R. (2017). Pengaruh tekanan dan ukuran partikel terhadap kualitas briket arang cangkang coklat. Jurnal Aplikasi Fisika, 13(2), 1-8.

Maharani, E. (2018). Perancangan jobsheet mata pelajaran pengolahan diversifikasi hasil perikanan untuk meningkatkan hard skill siswa di SMKN 1 Mundu Cirebon. Undergraduate Thesis, Universitas Pendidikan Indonesia.

Maknun, J., Barliana, M. S., and Cahyani, D. (2019). A design model of special vocational high school for children with visual impairment. Indonesian Journal of Science and Technology, 4(2), 158-170.

Nandiyanto, A. B. D., Asyahidda, F. N., Danuwijaya AA, Abdullah, A. G., Amelia, N., Hudha, M. N., and Aziz, M. (2018). Teaching "nanotechnology" for elementary students with deaf and hard of hearing. Journal of Engineering Science and Technology, 13(5), 1352-1363.

Nwabue, F. I., Unah, U., and Itumoh, E. J. (2017). Production and characterization of smokeless bio-coal briquettes incorporating plastic waste materials. Environmental Technology and Innovation, 8, 233-245.
Okot, D. K., Bilsborrow, P. E., and Phan, A. N. (2018). Effects of operating parameters on maize cob briquette quality. Biomass and Bioenergy, 112, 61-72.

Orisaleye, J. I., Jekayinfa, S. O., Adebayo, A. O., Ahmed, N. A., and Pecenka, R. (2018). Effect of densification variables on density of corn cob briquettes produced using a uniaxial compaction biomass briquetting press. Energy Sources, Part A: Recovery, Utilization, and Environmental Effects, 40(24), 3019-3028.

Pandey, S., and Dwivedi, N. (2020). Utilisation and management of agriculture and food processing waste. In: Mishra P., Mishra R.R., Adetunji C.O. (eds) Innovations in Food Technology, 269-288.

Peterria, V., and Suryani, N. (2016). Pengaruh lingkungan sekolah, cara belajar, dan motivasi belajar terhadap hasil belajar siswa pada mata pelajaran mengelola peralatan. Economic Education Analysis Journal, 5(3), 860860 .

Priyanto, A., Hantarum, H., and Sudarno, S. (2018). Pengaruh variasi ukuran partikel briket terhadap kerapatan, kadar air, dan laju pembakaran pada briket kayu sengon. In Prosiding Seminar Nasional Sains dan Teknologi Terapan, 541-546.

Purwanto, D. (2015). Pengaruh ukuran partikel tempurung sawit dan tekanan kempa terhadap kualitas biobriket. Jurnal Penelitian Hasil Hutan, 33(4), 303-313.

Putri, R. E., and Andasuryani, A. (2017). Studi mutu briket arang dengan bahan baku limbah biomassa. Jurnal Teknologi Pertanian Andalas, 21(2), 143-151.

Pratama, Yudistira, Helwani, Z., and Komalasari. (2017). Pembuatan briket pelepah sawit menggunakan proses torefaksi pada variasi tekanan dan penambahan perekat tapioka. Doctoral Dissertation, Riau University.

Rahman, K. A. (2020). Management of learning facilities to support the quality of education at state vocational high school of agriculture development Jambi. International Jurnal of Education Schoolars, 1(2), 49-57.

Safitri, E., Handayani, S., and Mujdalipah, S. (2018). Pembelajaran praktikum dengan modul berbasis science, technology, engineering and mathematics (STEM) untuk meningkatkan hasil belajar siswa pada kompetensi dasar melakukan dasar pengawetan. Edufortech, 3(2), 93-100.

Siregar, Y. (2020). Analysis of biobriquette from rice husk for biomass power plants: A review. In 2020 4rd International Conference on Electrical, Telecommunication and Computer Engineering (ELTICOM), 224-228.

Sunardi, S., Djuanda, D., and Mandra, M. A. S. (2019). Characteristics of charcoal briquettes from agricultural waste with compaction pressure and particle size variation 
as alternative fuel. International Energy Journal, 19(1), 139148 .

Tippayawong, K. Y., Santiteerakul, S., Ramingwong, S., and Tippayawong, N. (2019). Cost Analysis of Community Scale Smokeless Charcoal Briquette Production from Agricultural and Forest Residues. Energy Procedia, 160, 310-316.

Tumuluru, J. S., and Fillerup, E. (2020). Briquetting characteristics of woody and herbaceous biomass blends: impact on physical properties, chemical composition, and calorific value. Biofuels, Bioproducts and Biorefining, 14(5), 1105-1124.

Wahyuraidha, S. L. P. (2020). Pengembangan jobsheet untuk menumbuhkan kreativitas siswa pada praktikum pengolahan produk rempah dan bahan penyegar. Undergraduate Thesis, Universitas Pendidikan Indonesia.

Widyastuti, R., and Utami, I. S. (2018). Development of product-based job sheet as instructional media in vocational education. Journal of Educational Science and Technology (EST), 4(2), 119-125. 